\title{
ANALISIS KESULITAN SISWA MTS KELAS VIII DALAM MENYELESAIKAN SOAL CERITA SISTEM PERSAMAAN LINEAR DUA VARIABEL (SPLDV) DITINJAU DARI PERBEDAAN GENDER
}

\author{
Anti Maspupah ${ }^{1}$, Alan Purnama ${ }^{2}$ \\ ${ }^{1,2}$ IKIP SILIWANGI, Jl. Terusan Jendral Sudirman, Cimahi tengah, Kota Cimahi, Jawa Barat \\ antimasfufah31@gmail.com
}

\begin{abstract}
This study aims to analyze the difficulties of students in solving story questions on the Material Variable Linear Equation System (SPLDV) in terms of gender differences. This type of research is a case study. The subjects in this study were 8 students, namely 4 female students and 4 male students. The instrument in the research was a test in the form of a description of 3 questions concerning the Two Variable Linear Equation System (SPLDV). The average percentage of female students was $26.7 \%$ and the percentage of male students was $18.3 \%$. Both values are below $50 \%$ and are categorized as low. For question 1, the percentage of answers of female students is $35 \%$ while male students are $20 \%$. For questions no. 2, the percentage of female students and male students was the same, namely $10 \%$. For questions number 3 the percentage of female students was $35 \%$ and male students were $25 \%$. Difficulties of students in completing story questions material Two Variable Linear Equation System (SPLDV) is difficult for students to change story problems into mathematical sentences, students have difficulty understanding the information presented so they cannot make a solution, students cannot determine the set of solutions using elimination and substitution and students have difficulty understanding the SPLDV concept.
\end{abstract}

Keywords: Mathematics, Two Variable Linear Equation System

\begin{abstract}
Abstrak
Penelitian ini bertujuan menganalisis kesulitan siswa dalam menyelesaikan soal cerita pada materi Sistem Persamaan Linear Dua Variabel (SPLDV) ditinjau dari perbedaan gender . Jenis penelitian yang dilakukan adalah studi kasus. Subjek dalam penelitian ini sebanyak 8 siswa, yaitu 4 siswa perempuan dan 4 siswa laki-laki. Instrumen dalam penelitian adalah tes berbentuk uraian sebanyak 3 soal mengenai Sistem Persamaan Linear Dua Variabel (SPLDV). Presentase rata-rata siswa perempuan sebesar 26,7\% dan presentase siswa laki-laki sebesar 18,3\%. Nilai keduanya di bawah $50 \%$ dan dikategorikan rendah. Untuk soal no 1 presentase jawaban siswa perempuan $35 \%$ sedangkan siswa laki-laki $20 \%$. Untuk soal no 2 presentase jawaban siswa perempuan dan siswa laki-laki sama yaitu $10 \%$. Untuk soal no 3 presentase jawaban siswa perempuan 35\% dan siswa laki laki $25 \%$. Kesulitan siswa dalam menyelesaikan soal cerita materi Sistem Persamaan Linear Dua Variabel (SPLDV) adalah siswa sulit dalam mengubah soal cerita ke dalam kalimat matematika, siswa sulit memahami informasi yang disajikan sehingga tidak dapat membuat penyelesaian, siswa tidak dapat menentukan himpunan penyelesaian menggunakan eliminasi dan substitusi dan siswa sulit memahami konsep SPLDV.
\end{abstract}

Kata Kunci: Matematika, Sistem Persamaan Linear Dua Variabel

\section{PENDAHULUAN}

Matematika adalah ilmu yang sangat penting untuk dipelajari dan dikuasai (Bernard \& chotimah, 2018; Siswanto, 2018). Matematika perlu dipahami dan dikuasai oleh semua lapisan masyarakat terutama siswa di sekolah. Matematika merupakan ilmu yang membantu dalam mencari penyelesaian untuk berbagai masalah dalam kehidupan. Tidak dapat dipungkuri, bahwa tidak ada hari yang terlewat begitu saja tanpa penguasaan prinsip-prinsip matematika, mulai dari matematika sederhana sampau matematika tingkat tinggi. Terdapat banyak materi dalam pembelajaran matematika, salah satunya adalah materi Sistem Persamaan Linear Dua Variabel (SPLDV). Materi SPLDV merupakah salah satu kompetensi yang harus dikuasai oleh siswa kelas VIII Sekolah Menengah Pertama (SMP) dalam kurikulum 2013. Materi tersebut merupakan materi yang erat hubungannya dalam kehidupan sehari-hari dikarenakan banyak hal-hal yang kita temui menggunakan prinsip SPLDV seperti 
menghitung harga suatu barang pada saat berbelanja, dimana kita hanya mengetahui total belanja beberapa barang tanpa tahu pasti harga satuan barang yang dibeli. Materi SPLDV memiliki beberapa kegiatan dalam pembelajarannya, Diantaranya: membuat bentuk Persamaan Linear Dua Variabel (PLDV), membuat model masalah dari Persamaan Linear Dua Variabel, membuat model masalah dari Sistem Persamaan Linear Dua Variabel (SPLDV), dan menuliskan penyelesaian masalah yang berkaitan dengan SPLDV.

Matematika adalah bahasa simbolis yang fungsi praktisnya untuk mengekspresikan hubunganhubungan kuantitatif serta keruangan. Fungsi teoritisnya yaitu memudahkan dalam berpikir. Alasan betapa pentingnya matematika diberikan kepada siswa adalah selalu digunakan di berbagai kegiatan kehidupan sehari-hari (Nurhayati, 2019; Bernard, 2018), hampir semua pembelajaran melibatkan matematika, sarana komunikasi menjadi kuat,menghadirkan informasi dalam berbagai cara, melatih kemampuan berpikir secara logis dan memberikan kepuasan dalam upaya usaha memecahkan masalah menantang (Akbar, 2018). Russeffendi (Fauziah, 2019) menyatakan bahwasanya kegunaan matematika itu sangat besar, baik dalam ilmu pengetahuan, menjadi alat maupun dalam membentuk sikap. Matematika menjadi amat penting dalam pendidikan masyarakat baik sebagai objek langsung maupun objek tak langsung.

Alasan pentingnya matematika untuk dipelajari karena segudang manfaatnya. Di bawah ini kegunaan matematika sederhana yang praktis menurut Russeffendi (Isnaeni, 2019), yaitu: 1) Dengan belajar matematika kita mampu berhitung dan mampu melakukan perhitungan-perhitungan lainnya; 2). Matematika merupakan persyaratan untuk beberapa mata pelajaran lainnya; 3) Dengan belajar matematika perhitungan menjadi lebih sederhana dan praktis; dan 4) Dengan belajar matematika diharapkan kita mampu menjadi manusia yang berpikir logis.

Selama ini pandangan bahwa matematika merupakan pelajaran menakutkan belum hilang. Hal ini terlihat karena siswa masih sering mengalami kesulitan untuk mempelajari matematika yang objek kajiannya tidak konkret. Seperti yang diutarakan Soedjadi (Farida, 2015) karakteristik matematika, yaitu: 1) Memiliki objek kajian yang abstrak; 2) Bertumpu pada kesepakatan; 3) Berpola pikir deduktif; 4) Memiliki simbol yang kosong dari arti; 5) Memperhatikan semesta pembicaraan; dan 6) Konsisten dalam sistemnya.

Menurut Jamal (2019) kesulitan atau kendala belajar yang dialami siswa dapat disebabkan oleh faktor internal dan juga faktor eksternal. Faktor internal berasal dari dalam siswa sendiri, contohnya kesehatan, minat serta bakat, motivasi (dorongan), kemampuan untuk bertindak (intelegensi) dan lain sebagainya. Sedangkan faktor eksternal berasal dari luar diri siswa misalnya dari lingkungan di sekolah, lingkungan dalam keluarga serta lingkungan yang ada di masyarakat. Kesulitan siswa belajar matematika adalah kesulitan belajar konsep, 3 hal penyebab siswa mengalami kesulitan dalam belajar matematika diantaranya adalah persepsi, intervensi serta ekstrafolasi dalam pelaksanaan proses belajar mengajar akan sangat menentukan sejauh mana keberhasilan yang harus dicapai dalam matematika. Kesulitan belajar bisa berakibat pada prestasi belajar siswa karena untuk memperoleh prestasi yang baik 
dapat diperoleh dari perlakuan belajar di sekolah maupun diluar sekolah dan atas ketentuan serta usaha siswa saat belajar. Hal serupa juga terjadi disaat belajar matematika, maka dari itu memahami kesulitan belajar siswa dalam pelajaran matematika penting bagi guru dijadikan masukan untuk memperbaiki proses belajar mengajar di kelas.

Secara lebih khusus dalam belajar matematika yang baik menurut Russeffendi (Jamal, 2019) adalah supaya anak didik memahami serta mengerti konsep pada matematika, alangkah baiknya diajarkan urutan konsep murni selanjutnya dengan konsep terapan di samping itu harus disesuaikan dengan tingkat-tingkat proses anak didik atau peserta didik belajar. Menurut Fitriani (2018) konsep matematika harus dibangun di benak siswa melalui proses pembelajaran yang bermakna, tidak ditransfer secara langsung, atau menekankan siswa untuk menghafalnya saja (Bernard, 2014).

Berdasarkan peneltian Puspitasari (2015) kesulitan dihadapi siswa pada saat menyelesaikan soal cerita dalam materi SPLDV adalah kesulitan menentukan dan memisalkan variabel, mengubah soal cerita menjadi bentuk model matematika, kesulitan menggunakan metode eliminasi juga substitusi, siswa juga sulit mengoperasikan penjumlahan dan juga pengurangan, kesulitan menentukan nilai variabel. Faktor yang menjadi penyebab kesulitan tersebut adalah rendahnya tingkat penguasaan materi SPLDV, siswa kurang tekun, siswa kurang teliti pada saat memecahkan soal dan siswa tidak menguasai konsep serta prinsip SPLDV.

Penelitian mengenai analisis kesulitan siswa pada materi SPLDV berdasarkan perbedaan gender juga dilakukan oleh Safitri (2019) menunjukkan bahwa (1) pada tahap memahami masalah memiliki kesulitan akan tetapi memiliki kategori sedang dan pada menyusun rencana peserta didik memiliki kesulitan akan tetapi kategori yang rendah, untuk tahap melaksanakan rencana peserta didik memiliki kesulitan dengan kategori tinggi diantaranya kesulitan mengoperasikan perhitungan secara tepat, sulit untuk memahami konsep dengan metode yang akan digunakan, siswa perempuan dan siswa laki-laki kesulitan untuk meneliti setiap proses yang dilakukannya karena kurangnya penguasaan metode serta perhitungan, siswa kesulitan dalam pemahaman konsep yang tersedia sehingga siswa hanya mengacu kepada rumus dan ingatan. Pada tahap melihat kembali peserta didik kesulitan dengan kategori tinggi diantaranya siswa laki-laki dan perempuan kesulitan untuk mengevaluasi jawaban karena tidak ada pembiasaan untuk meneliti kembali apa yang diperoleh serta malas untuk mengoreksi kembali jawabannya karena ketika siswa melakukan evaluasi dianggap memerlukan waktu lama. (2) Beberapa faktor dialami siswa ditinjau dari kedua gender beranggapan bahwa kurangnya pemahaman dan penguasaan materi SPLDV menggunakan tiga metode secara runtut, kurang menguasai langkah perhitungan secara keseluruhan, kurangnya ketelitian, kurangnya latihan dengan soal-soal, siswa cenderung terburu-buru dalam menetukan hasilnya, merasa ragu dengan hasil yang telah dikerjakan serta faktor dari guru yang menggunakan metode mengajar konvensional (Rustyani, 2019) dan tidak fokus dalam pengerjaan (Hidayat, 2019).

Hidayah (2016) menyimpulkan bahwa analisis kesalahan dalam menyelesaikan soal cerita 
SPLDV berdasarkan langkah penyelesaian Polya siswa kelas X IPA 3 SMA Negeri 3 Jember adalah sebagai berikut. a) Kesalahan memahami soal, dapat dilihat dari hasil pekerjaan siswa ketika menuliskan apa yang diketahui dan ditanya dari soal yang diberikan, yaitu terdapat kata penting yang sering tidak dituliskan siswa. b) Kesalahan menyusun rencana, dapat dilihat dari hasil pekerjaan siswa yaitu ketika siswa tidak menuliskan pemisalan variabel dari soal cerita yang diberikan, siswa tidak membuat model matematika yang sesuai dengan kalimat cerita yang ada pada soal serta tidak menuliskan metode dan langkah-langkah yang akan mereka gunakan dalam menyelesaikan model matematika yang telah dibuatnya. c) Kesalahan melaksanakan rencana, dilihat dari hasil pekerjaan siswa yaitu ketika siswa tidak menyelesaikan model matematika yang telah dibuatnya sesuai dengan langkah-langkah penyelesaian yang telah disusunnya, siswa lupa atau salah menuliskan operasi dalam perhitungan; salah dalam menghitung; dan salah dalam menuliskan satuan serta tidak menuliskan kesimpulan sesuai dengan permasalahan yang diberikan. d) Kesalahan memeriksa kembali solusi yang diperoleh, dilihat dari hasil pekerjaan siswa yaitu ketika siswa menuliskan pembuktian tanpa melalui langkah-langkah yang seharusnya diselesaikan terlebih dahulu (sistematis).

Penelitian yang sama juga dilakukan Idris (2016), sebagian besar siswa kelas VIII-a SMP Islam Jailolo masih mengalami kesulitan dalam menyelesaikan soal-soal penerapan Sistem Persamaan Linear Dua Variabel. Kesulitan yang dialami siswa ditandai dengan adanya kesalahankesalahan siswa dalam menjawab soal yang berkaitan dengan SPLDV. Adapun kesalahan yang dimaksud adalah diantarnya adalah (a) Kesalahan dalam menempatkan lambang-lambang yang membentuk SPLDV, (b) Kesalahan dalam merumuslan model matematika yang berkaitan dengan SPLDV, (c) Kesalahan kesalahan dalam menggunakan sifat-sifat penambahan dan perkalian pada persamaan, dan (d) Kesalahan dalam melakukan operasi pada bilangan. Selanjutnya secara berturut-turut disebut kesalahan fakta, kesalahan konsep, kesalahan prinsip, dan kesalahan skill

Berdasarkan penjelasan diatas peneliti tertarik menganaliss kesalahan siswa di tinjau dari perbedaan gender khususnya materi Sistem Persamaan Linear Dua Variabel (SPLDV). Kesalahan menyelesaikan soal cerita Sistem Persamaan Linear Dua Variabel dapat dimanfaatkan untuk mendeteksi kesulitan belajar matematika sehingga dapat menemukan solusi yang tepat dalam menyelesaikan soal cerita SPLDV. Hasibuan (2015) menyatakan bahwa kesalahan yang terjadi pada penyelesaian soal SPLDV tidak terlepas dari materi sebelumnya yang belum dikuasai dengan baik, seperti operasi bentuk aljabar. Maka dengan memantapkan kembali materi sebelumnya, hal itu bisa dijadikan solusi untuk mengatasi kesulitan siswa dalam menyelesaikan soal yang berkaitan dengan SPLDV.

\section{METODE}

Metode penelitian yang digunakan adalah studi kasus dengan tujuan mendapatkan gambaran tentang kesulitan siswa dalam menyelesaikan soal cerita sistem persamaan linear dua variabel. 
Pengambilan subjek berdasarkan perbedaan gender. Subjek penelitian yaitu siswa kelas VIII pada salah satu MTs di Kota Cililin berjumlah 8 siswa, terdiri dari 4 siswa laki-laki dan 4 siswa perempuan. Materi penelitian adalah Sistem Persamaan Linear Dua Variabel (SPLDV). Instrumen penelitian adalah tes uraian sebanyak 3 soal. Dalam penelitian ini peneliti membandingkan hasil presentase jawaban kedua gender dalam menyelesaikan soal cerita SPLDV. Adapun rumus untuk memperoleh presentase tersebut adalah:

$$
P=\frac{n}{N} \times 100 \%
$$

Keterangan:

$\mathrm{P}=$ Presentase jawaban benar siswa

$\mathrm{n}=$ Jumlah jawaban benar siswa

$\mathrm{N}=$ Jumlah keseluruhan untuk jawaban benar

\section{HASIL}

Setelah dilakukan tes terhadap 4 siswa perempuan dan 4 siswa laki-laki pada materi Sistem Persamaan Linear Dua Variabel (SPLDV) menggunakan instrumen tes sebanyak 3 soal uraian, didapat hasil tes sebagai berikut:

\section{Tabel 1.}

Hasil tes siswa

\begin{tabular}{ccccccc}
\hline \multirow{2}{*}{ Nama } & \multirow{3}{*}{ Gender } & $\mathbf{1}$ & $\mathbf{2}$ & $\mathbf{3}$ & $\mathbf{4}$ & Jumlah \\
\cline { 3 - 6 } & & $\mathbf{5}$ & $\mathbf{5}$ & $\mathbf{5}$ & $\mathbf{5}$ & $\mathbf{2 0}$ \\
\cline { 3 - 6 } S-1 & Perempuan & 2 & 0 & 2 & 1 & 5 \\
\hline S-2 & Perempuan & 1 & 0 & 2 & 1 & 4 \\
\hline S-3 & Perempuan & 2 & 1 & 1 & 1 & 5 \\
\hline S-4 & Perempuan & 2 & 1 & 2 & 1 & 6 \\
\hline & Presentase & $35 \%$ & $10 \%$ & $35 \%$ & $20 \%$ & $25 \%$ \\
\hline S-5 & Laki-laki & 1 & 1 & 1 & 0 & 3 \\
\hline S-6 & Laki-laki & 1 & 1 & 1 & 0 & 3 \\
\hline S-7 & Laki-laki & 0 & 0 & 1 & 0 & 1 \\
\hline S-8 & Laki-laki & 2 & 0 & 2 & 1 & 5 \\
\hline & Presentase & $20 \%$ & $10 \%$ & $25 \%$ & $5 \%$ & $15 \%$ \\
\hline
\end{tabular}

Tabel diatas menunjukkan bahwa presentase rata-rata siswa perempuan lebih tinggi dari pada presentase siswa laki-laki dalam menyelesaikan soal cerita materi Sistem Persamaan Linear Dua Variabel (SPLDV). Presentase rata-rata siswa perempuan sebesar 25\% dan presentase siswa laki-laki sebesar $15 \%$. Presentase tersebut dibawah 50\%. Hal ini menunjukkan bahwa kemampuan siswa menyelesaikan soal cerita materi sistem persamaan linear dua variabel (SPLDV) dikategorikan rendah. 
Pada soal no 1 presentase siswa perempuan 35\% dan presentase siswa laki-laki sebesar $20 \%$. Untuk soal no 2 siswa laki-laki dan siswa perempuan memperoleh presentase yang sama yaitu $10 \%$ sedangkan soal no 3 presentase siswa perempuan lebih unggul yaitu sebesar $35 \%$ dan presentase siswa laki-laki sebesar $25 \%$.

Tabel 1 menunjukkan hasi tes dari 4 orang siswa laki-laki dan 4 orang siswa perempuan. Hasil tes menunjuukan bahwa untuk setiap soal siswa belum mampu menjawab dengan benar bahkan masih ada siswa yang tidak menjawab sama sekali untuk beberapa soal. Untuk soal no 1, satu orang siswa laki laki tidak dapat menjawab. Untuk soal no 2, dua orang siswa laki-laki dan dua orang siswa perempuan tidak dapat menjawab. Untuk soal no 4, tiga orsng siswa laki-laki yang tidak menjawab. Berikut contoh jawaban siswa:

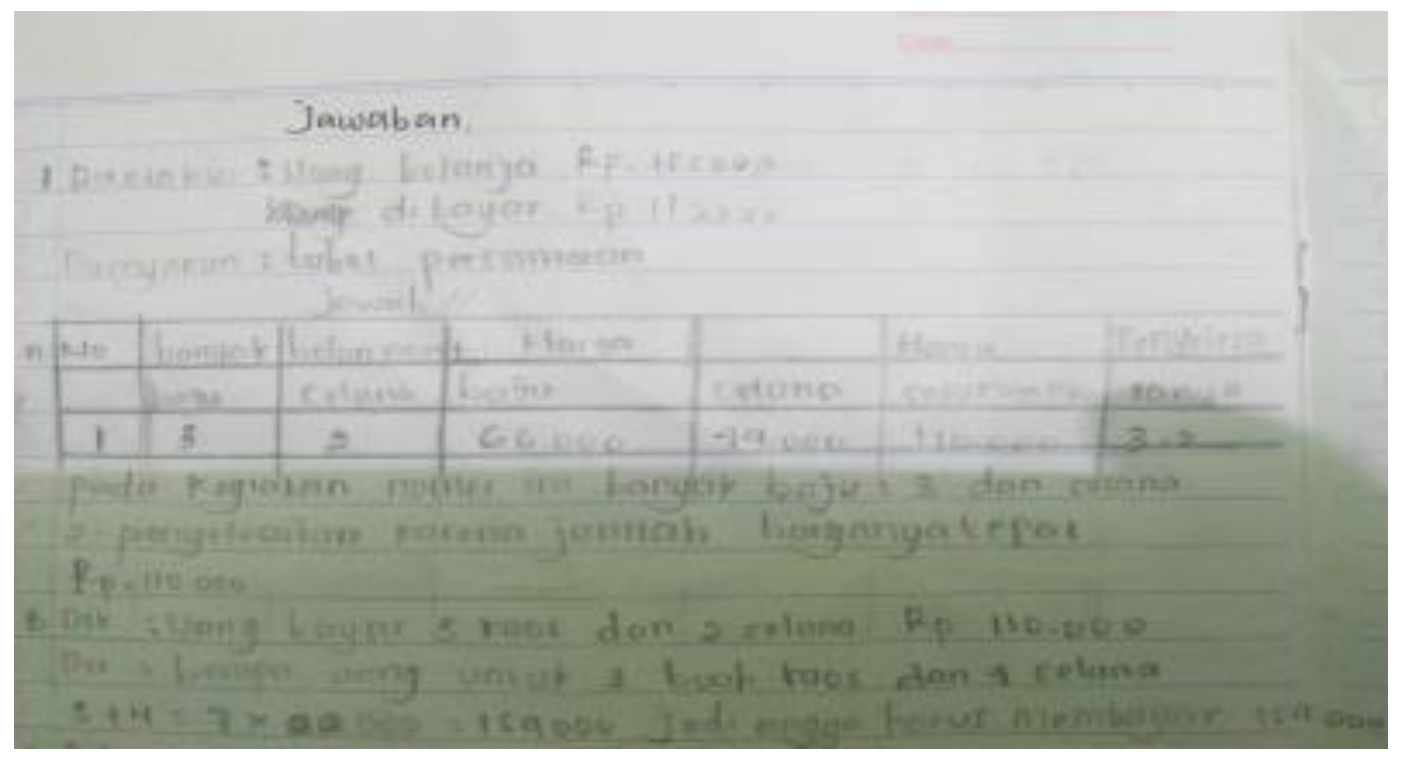

Gambar 1. Jawaban Siswa dalam Menjawab Soal No 1

Pada soal no 1 bagian a siswa diminta menyajikan informasi dalam bentuk tabel persamaan dan menentukan penyelesaiannya. Kemudian untuk bagian b siswa diminta menghitung besar uang yang harus dibayar untuk membeli 3 buah kaos dan 4 buah celana dengan merk yang sama yang dibeli Giri dan Bima. Dari jawaban siswa pada gambar 1, siswa tidak bisa mengubah informasi ke dalam bentuk tabel persamaan secara lengkap siswa hanya menuliskan bahwa 3 buah baju seharga Rp 66.000, 2 buah celana seharga Rp 44.000 dan jumlah keseluruhannya sebesar Rp 110.000. Karena kurangnya siswa memahami informasi maka mereka tidak dapat menentukan harga untuk masing-masing baju dan celana. Siswa kesulitan untuk menetukan penyelesaian SPLDV baik itu cara eliminasi maupun substitusi sehingga siswa kebingungan menghitung besar uang yang diminta. Jadi untuk soal no 1 siswa tidak mampu menentukan besar uang yang diperlukan untuk membayar 3 buah kaos dan 4 buah celana. Terlihat dari tabel 1 nilai presentase jawaban untuk soal no1 siswa perempuan 35\% dan siswa laki-laki $20 \%$. 


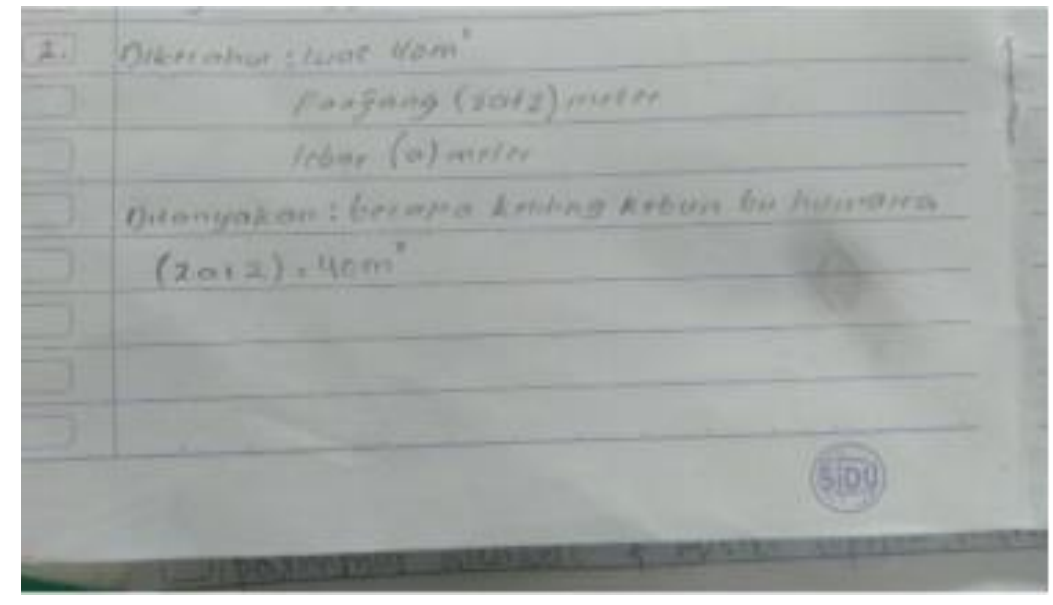

Gambar 2. Jawaban siswa dalam menjawab soal no 2

Pada soal no 2 siswa diminta menyusun persamaan dari informasi yang disajikan kemudian siswa diminta menentukan keliling persegi panjang, dengan lebar (a)m, panjang $(2 \mathrm{a}+2) \mathrm{m}$ dan luas $40 \mathrm{~m}^{2}$. Dilihat dari jawaban siswa pada gambar 2, siswa tidak bisa mengubah soal cerita kedalam kalimat matematika sehingga siswa tidak dapat membuat persamaan dari informasi yang terdapat dalam soal. Adapun siswa menuliskan persamaan yang salah yaitu panjang sama dengan luas. Selain itu dari jawaban siswa terlihat jelas bahwa siswa tesebut memahami apa yang ditanyakan akan tetapi dia tidak dapat membuat perencanaan dalam menjawab. Jadi untuk soal no 2 siswa tidak dapat menentukan keliling persegi panjang. Pada tabel terlihat jelas nilai presentase jawaban untuk soal no 2 dari kedua gender adalah sama yaitu $10 \%$.

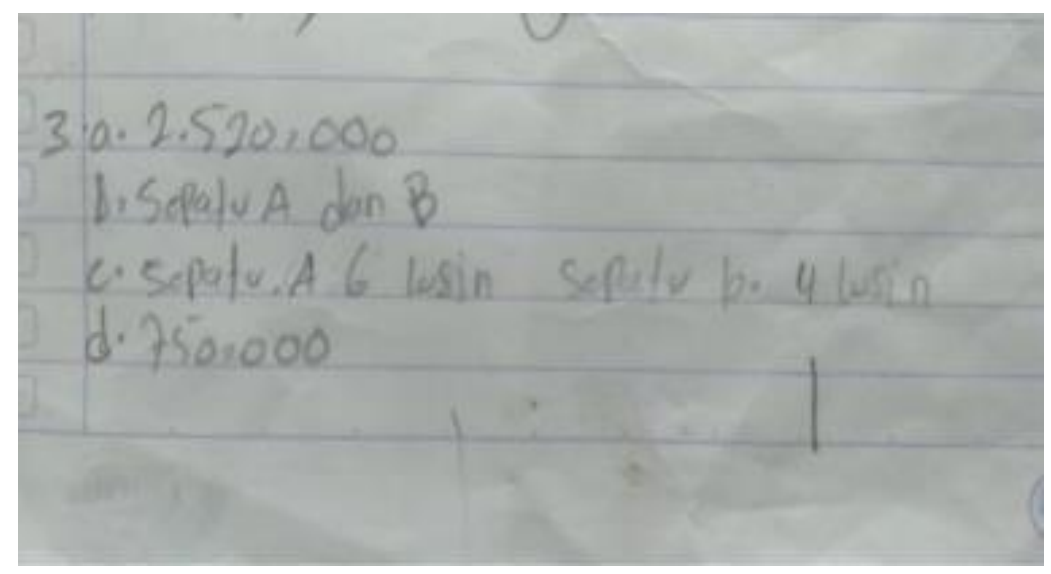

Gambar 3. Jawaban siswa dalam menjawab soal no 3

Pada soal no 3 siswa diminta menentukan harga beli dan harga jual dari 2 merk sepatu yang berbeda, membuat persamaan dari informasi yang disajikan, menghitung rata-rata sepasang sepatu dari masing masing merk yang dijual oleh pak Rahmat serta menghitung presentase rata-rata pada kegiatan jual beli 
yang dilakukan pak Rahmat. Dari gambar 3, siswa menjawab secara lansung tanpa menuliskan alternatif penyelesaian, siswa tidak memahami masalah sehingga jawaban siswa tidak sesuai dengan persoalan yang ditanyakan. Dari jawaban siswa jelas bahwa siswa tidak menguasai konsep dan prinsip SPLDV sama sekali. Jadi untuk soal no 3 siswa juga tidak dapat menyelesaikan soal dengan baik, terlihat nilai presentase jawaban soal no 3 yaitu $35 \%$ untuk siswa perempuan dan $25 \%$ untuk siswa laki-laki.

\section{KESIMPULAN}

Berdasarkan hasil penelitian yang telah diuraikan, kemampuan siswa perempuan dalam menyelesaikan soal Sistem Persamaan Linear Dua Variabel lebih baik dari siswa laki-laki. Hal ini terlihat dari presentase rata-rata siswa perempuan sebesar $26,7 \%$ dan presentase siswa laki-laki sebasar 18,3\%. Nilai keduanya di bawah 50\% dan dikategorikan rendah. Adapun kesulitan siswa menyelesaikan soal cerita materi Sistem Persamaan Linear Dua Variabel (SPLDV) adalah siswa sulit mengubah soal cerita ke dalam kalimat matematika, siswa sulit memahami informasi yang disajikan sehingga tidak dapat membuat penyelesaian, siswa tidak dapat menentukan himpunan penyelesaian menggunakan metode metode dalam menyelesaikan SPLDV dan siswa sulit memahami konsep SPLDV.

\section{DAFTAR PUSTAKA}

Akbar, P., Hamid, A., Bernard, M., \& Sugandi, A. I. (2018). Analisis kemampuan pemecahan masalah dan disposisi matematik siswa kelas xi sma putra juang dalam materi peluang. Jurnal Cendekia: Jurnal Pendidikan Matematika, 2(1), 144-153.

Bernard, M. (2014). Pengaruh pembelajaran dengan menggunakan multimedia macromedia falsh terhadap kemampuan penalaran matematik. In Prosiding Seminar Nasional Pendidikan Matematika Program Pasca Sarjana STKIP Siliwangi Bandung (Vol. 1, pp. 425-429).

Bernard, M. (2015). Meningkatkan kemampuan komunikasi dan penalaran serta disposisi matematik siswa SMK dengan pendekatan kontekstual melalui game adobe flash cs 4.0. Infinity Journal, 4(2), 197-222.

Bernard, M., \& Chotimah, S. (2018, September). Improve student mathematical reasoning ability with open-ended approach using VBA for powerpoint. In AIP Conference Proceedings (Vol. 2014, No. 1, p. 020013). AIP Publishing LLC.

Bernard, M. (2018). Meningkatkan Kemampuan Berpikir Kreatif Mahasiswa Matematik Melalui Pendekatan Problem Posing Berbantuan Visual Basic Application For Microsoft Excel. JPMI (Jurnal Pembelajaran Matematika Inovatif), 1(1), 69-78.

Farida, N. (2015). Analisis Kesalahan Siswa SMP Kelas VIII dalam Menyelesaikan Masalah Soal Cerita Matematika. Aksioma: Jurnal Program Studi Pendidikan Matematika, 4(2). 
Fauziah, S. I., Zanthy, L. S., \& Kuswoyo, R. (2019). Pengaruh Pendekatan Pembelajaran Kontekstual Berbasis Multimedia terhadap Kemampuan Pemahaman Matematis Siswa SMP. Journal on Education, 1(2), 247-255.

Fitriani, N., D. S. (2018). Analysis of Mathematical Abstraction on Concept of A Three Dimensional Figure with Curved Surfaces of Junior High School Students . Journal of Physics: Conference Series, 1.

Hasibuan, I. (2015). Hasil Belajar Siswa pada Materi Bentuk Aljabar di Kelas VII SMP Negeri Banda Aceh Tahun Pelajaran 2014/2015. Jurnal Peluang, 4(1), 5-11

Hidayah, S. (2016). Analisis kesalahan siswa dalam menyelesaikan soal cerita SPLDV berdasarkan langkah penyelesaian Polya. In Prosiding Seminar Nasional Pendidikan Matematika (Vol. 1, No. 29, pp. 182-190).

Hidayat, F., Akbar, P., \& Bernard, M. (2019). Analisis Kemampuan Berfikir Kritis Matematik Serta Kemandiriaan Belajar Siswa Smp Terhadap Materi Spldv. Journal on Education, 1(2), 515523.

Idris, F. H., Hamid, I., \& Ardiana, A. (2016). Analisis kesulitan siswa dalam menyelesaikan soal-soal penerapan sistem persamaan linear dua variabel. Delta-Pi: Jurnal Matematika dan Pendidikan Matematika, 3(2).

Isnaeni, S., \& Zanthy, L. S. (2019). Penerapan Pendekatan Kontekstual untuk Meningkatkan Kemampuan Koneksi Matematis Siswa SMP pada Materi Persamaan dan Pertidaksamaan Linear Satu Variabel. Journal on Education, 1(3), 59-64.

Jamal, F. (2019). Analisis Kesulitan Belajar Siswa dalam Mata Pelajaran Matematika pada Materi Peluang Kelas XI IPA SMA Muhammadiyah Meulaboh Johan Pahlawan. MAJU: Jurnal Ilmiah Pendidikan Matematika, 1(1).

Nurhayati, N., \& Bernard, M. (2019). Analisis Kesulitan Siswa Dalam Pemecahan Masalah Matematik Siswa Kelas X SMK Bina Insan Bangsa Pada Materi Persamaan Dan Pertidaksamaan. Journal on Education, 1(2), 497-502.

Puspitasari, E., Yusmin, E., \& Nursangaji, A. (2015). Analisis Kesulitan Siswa Menyelesaikan Soal Cerita Materi Sistem Persamaan Linear Dua Variabel DI SMP. Jurnal Pendidikan dan Pembelajaran, 4(5)

Rustyani, N., Komalasari, Y., Bernard, M., \& Akbar, P. (2019). Upaya Meningkatkan Disposisi Dengan Pendekatan Open Ended Pada Siswa Smk Kelas X-Rpl B. Journal on Education, 1(2), 265270.

Safitri, A. E., \& Toyib, M. (2019). Kesulitan Siswa Berdasarkan Teori Polya Ditinjau dari Gender dalam Menyelesaikan Soal Sistem Persamaan Linear Dua Variabel (SPLDV) Di SMP Negeri 1 Sambi (Doctoral dissertation, Universitas Muhammadiyah Surakarta). 
Siswanto, R. D., Dadan, D., Akbar, P., \& Bernard, M. (2018). Penerapan Model Pembelajaran Kooperatif Tipe Auditorial, Intelectually, Repetition (Air) Untuk Meningkatkan Pemecahan Masalah Siswa Smk Kelas XI. Journal on Education, 1(1), 66-74. 